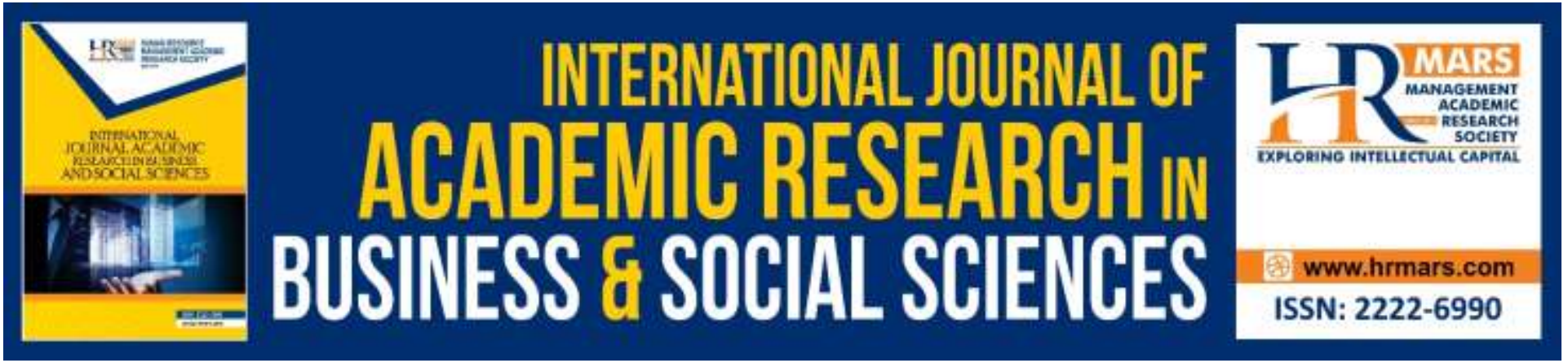

\title{
Iban Women and Side-Income Generation in Bintulu
}

\section{Anita Rosli, Adrian Daud \& Juniza Md Saad}

To Link this Article: http://dx.doi.org/10.6007/IJARBSS/v11-i17/11407 DOI:10.6007/IJARBSS/v11-i17/11407

Received: 13 August 2021, Revised: 16 September 2021, Accepted: 29 September 2021

Published Online: 14 October 2021

In-Text Citation: (Rosli et al., 2021)

To Cite this Article: Rosli, A., Daud, A., \& Saad, J. M. (2021). Iban Women and Side-Income Generation in Bintulu. International Journal of Academic Research in Business and Social Sciences, 11(17), 254-262.

Copyright: (C) 2021 The Author(s)

Published by Human Resource Management Academic Research Society (www.hrmars.com)

This article is published under the Creative Commons Attribution (CC BY 4.0) license. Anyone may reproduce, distribute, translate and create derivative works of this article (for both commercial and non-commercial purposes), subject to full attribution to the original publication and authors. The full terms of this license may be seen

at: http://creativecommons.org/licences/by/4.0/legalcode

Special Issue Title: Empowering Community and Beyond, iRandau, 2021, Pg. 254 - 262

Full Terms \& Conditions of access and use can be found at http://hrmars.com/index.php/pages/detail/publication-ethics 


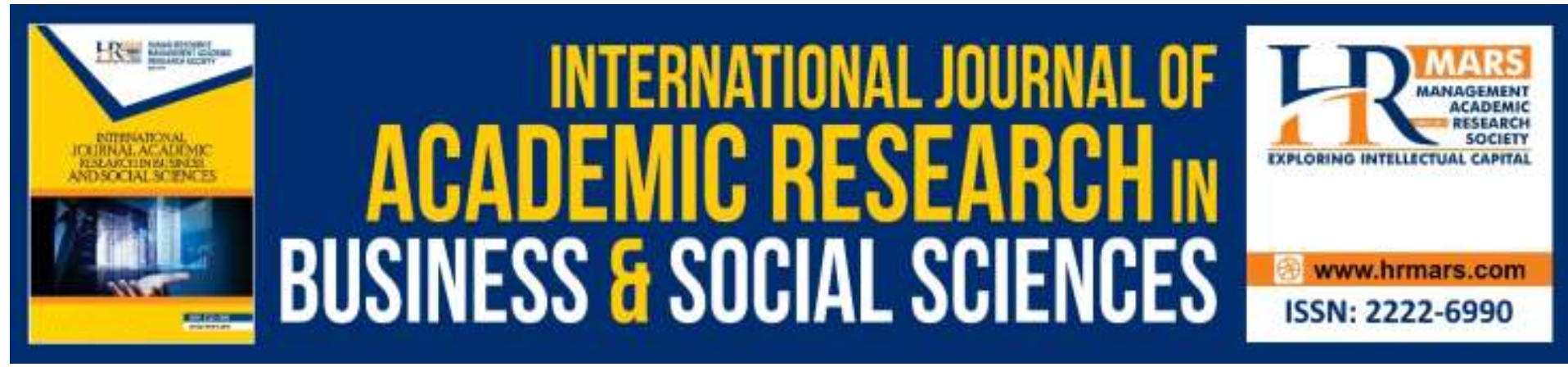

\title{
Iban Women and Side-Income Generation in Bintulu
}

\author{
Anita Rosli 1,2, Adrian Daud ${ }^{1,2} \&$ Juniza Md Saad ${ }^{3}$ \\ ${ }^{1}$ Department of Social Science \& Management, ${ }^{2}$ Institut Ekosains Borneo, ${ }^{3}$ Department \\ of Science and Technology, Universiti Putra Malaysia Bintulu Campus, 97000 Bintulu, \\ Sarawak, Malaysia. \\ Email: anitarosli@upm.edu.my
}

\begin{abstract}
Like other women, Iban women do several activities as the side-income generation to support family life such as farming, handicraft making, and traditional food processing and business. This study aims to investigate the involvement of Iban women in the side-income generation in Bintulu, Sarawak. Thus, the target population in this study is Iban women who are involved in side-income activities only as not all Iban women in Bintulu involve in sideincome activities. This study will identify the type of side-income activities and find out barriers to women's participation in side-income activities and propose relevant solutions to the problems. The questionnaire will be distributed to the target population and descriptive data analysis will be used to describe and summarize the findings. From the findings of the study, the researcher will come out with relevant suggestions to reduce and solve problems faced by Iban women in the side-income generation. For instance, propose appropriate programs and training to enhance their knowledge and skills in side-income activities that they preferred. Side-income generation among Iban women not only benefits the family but will create positive effects on Iban women development and empowerment in Sarawak generally.
\end{abstract}

Keywords: Side-income, Iban Women, Development, Empowerment

\section{Introduction}

Women are key to sustainable development and quality of life in the family and contribute to the socio-economic development of society. The existence of women over the time in transition or shift from traditional to modern. Women's roles are not limited to traditional roles (domestic sector) but are involved in transitional roles (public sector). The traditional roles refer to women's roles as wife, mother, and household' managers while the transitional roles refer to the participation in economic activities. The change in economic require most families to have a dual breadwinner. Women also play crucial roles as breadwinners to support family life either they are married, singles, or even single mothers as well. Sometimes, housewives become female-headed household as their husband migrates for employment and social prestige (Kelly, 2013). Thus, it is undeniable the great roles of women in the family 
as they play multi-roles, instead of their status as a wife, head of household and they become a breadwinner as well.

As a breadwinner, many women involved in informal sector, either as full-time or part-time activities because it is more flexible and concerning with "the demand of multiroles" and the informal sector do not insist on high education and skills (Ida \& Nurliani, 2016). Informal sectors refer to economic activities of workers and entities which are in law or practice not covered by formal arrangements (International Labour Organization (ILO)). In 2019, 9.4 percent of all females employed in Malaysia worked in the informal sector (Statista, 2021). According to Department Statistics Report, Malaysia (2020), more than 40 per cent of the activity in the informal sector operated at home, one third with no fixed location (mobile) and 18.1 per cent at market or street stalls. A majority of informal employment in the informal sector has Sijil Pelajaran Malaysia (SPM) below followed by degree and no certificate in 2017. However, the percentage share of informal employment among degree holders in the informal sector increased by 5.8 percentage points in 2017 to 8.6 per cent as compared to 2.8 per cent in 2015 with an annual growth rate of 48.1 per cent.

\section{Side-Income Generation Among Iban Women}

Sarawak is the largest state in Malaysia. Iban also known as "Sea Dayaks" ethnic represents almost $50 \%$ of Sarawak population. Due to the culture of bajalai (sojurn), there are between 30,000 and 40,000 Iban population in Johor and a sizeable of Iban communities could be found in Kuala Lumpur seeking employment. They will return home during the Gawai Dayak and Christmas celebration.

Like other women, Iban women do several activities as daily life activities and source of income as well. Iban women in rural areas or longhouses involve in farming, fishing, handicraft, and processing food for personal use, sale, and exchange purposes. Longhouses communities tend to sell and swap their products with each other. Besides, they are also selling the products to the wholesaler or selling them in town areas (Sunday market). Nowadays, many Iban women migrate to urban areas following their husbands, for employment and even for a better life. Either they are full-time housewives or jobholders, some of them will earn side-income by doing home business activities such as handicraft making, baking, tailoring, cooking, and online business to support family life, as the living cost is expensive compared to living cost in rural areas. When they move to urban or town areas, some of their traditional activities are discontinued such as farming activities as they do not have land space for farming, like what they had in their village, unless they have knowledge and skills in modern farming such as hydroponic farming system. However, they could continue other activities such as handicraft making but it may differ in terms of raw materials and design. For example, rattan mat and bamboo basket may not be able to produce as the rattan and bamboo supply not always available in urban areas, but they use plastic packaging strip (PPS) as the main raw materials.

However, not all Dayak women succeed in business as they are facing some constraints such as less knowledge and skills, no start-up capital, and limited access to modern facilities such as telecommunication and the internet. For instance, Iban women who involve in farming may have limited knowledge in good agricultural practices, thus causing less effectiveness and efficiency in farm management. They have skills in handicraft making but they have limited knowledge in modern marketing method caused them difficult to market their products. Nowadays, online marketing is widely used to market products but some of them may not exposes to marketing applications (android phones) and limited 
access to internet facilities, especially in the rural area. They are willing to involve in handicraft making but do not have enough knowledge and skills to produce those handicrafts such as producing traditional costumes. As they move to town, they have less opportunity to learn handicraft making that is usually led by the older generation that stays in the village. Besides, they are also having less exposure or opportunity to join training programs that expose them to some skills such as tailoring, baking, entrepreneurship, etc. Some of them need start-up capital to start a home business but do not know where and how to get financial support from the government and related agencies. Those kinds of problems may hinder Iban women involved in side-income earning.

Thus, the purpose of this study is to investigate the involvement of Iban women in side-income generation in Bintulu, Sarawak. From this study, we could identify types of sideincome activities among Iban women in Sarawak. If there are obstacles in side-income earning, we could propose suitable solutions according to problems and situations. Different problems and situations need to be overcome by different approaches and methods. This study could be a reference to government and relevant agencies to plan strategies to help and improve Iban women development and empowerment.

\section{Research Objective (RO)}

The main objective of the study is to the involvement of Iban women in side-income generation in Bintulu, Sarawak. There are four sub-objectives constructed to support the main objective of the study. The sub-objectives as follows:

1. To identify the type of side-income activities

2. To investigate the factors of Iban women involved in side-income generation

3. To investigate obstacles to participate in side-income generation.

4. To propose relevant solutions to the problems.

\section{Literature Review}

The review of related findings on women's employability are influenced by their age, educational background, fertility restrictions, work-life balance and cohort effects (Sassler et al., 2017; Kriesi, Buchmann, \& Sacchi, 2010; Izmayani et al., 2016). Employers typically tends to rate the job options based on the job challenges and difficulties in which certain sectors being female-dominated, and others being male-dominated segments. Nonetheless, men employees continue to thrive decision-making roles in the majority of corporations and organisations. However, these does not reflect the ability of women to play an important role as an income earner in their family.

The designation of women as Agents of Change by United Nations in Climate Action demonstrated that women's distinctive abilities able to formulate strategies and develop solutions, particularly when they are empowered (United Nation Women Watch, 2009). In rural areas, the majority of incomes are dependent on local natural resources such as agricultural crops, fisheries, forestry, and mostly women are responsible in the domestic activities. Women's expertise and knowledge transfer on issues related to natural resources are extremely valuable in ensuring climate change mitigation (Adedeji et. al, 2018). Having said that, women's contributions not only beneficial in the context of climate change mitigation but this is also supporting the adaptation of women as family income earners.

In the agricultural sector in rural areas for example, the roles of women in farm and livestock-rearing are vital, either working on the family farms or outside family farms Pattnaik \& Lahiri-Dutt (2020). In the context of family farms, even if not as wage labourers but as 
jointly-owners within the family, contributions from women would greatly enhance their livelihoods. The finding by Krumbiegel, Maertens \& Wollni (2020). also discovered that women participation as wage labourers in the agricultural industry could potentially increase their family income $30 \%$ higher than unemployed women in the family. In addition to being directly involved in the farming activities, women are also involved in agricultural production operations and small-scale commercial ventures. Women in rural areas have recently shown a lot of interest in pursuing entrepreneurial careers. As studied by Padilla-Meléndeza \& Ciruela-Lorenzo (2018), for female indigenous entrepreneurs, they suggested that numerous drivers and inhibitors, including socio-cultural setting, government institutional supports, inheritance community, and self-individual traits, enhance the competitiveness of female indigenous entrepreneurs.

In spite of having significant contribution on family income, there are issues need to be addressed with regards to working women's welfare especially in the rural areas. Financial difficulties, job insecurity, concerns about hazardous employment, and home-related issues have all been linked to a higher risk of depressive illness or mental disorder among working women of low socioeconomic status Lipscomb et. al (2007). It was also shown that $75 \%$ of women diagnosed with depression had children in the home, which may indicate the childcare support issue. Childcare assistance by the employer as well as aid from parents or in-laws may be helpful to alleviate this concern (Arpino, Pronzato, \& Tavares, 2014). Apart from that, women working indoors including bread baking, carpet weaving and the use of biomass fuel might potentially expose to health issue risks such as asthma and chronic bronchitis (Mohammad, Mehri \& Mohammad, 2002).

There is a limited study on the role of women as family income earners notably in the Iban community. There are, indeed, many accomplished women in Sarawak who hold high-ranking positions both locally and internationally (Borneo Post, 2019). Their achievement in various sectors including economics and politics shows that women in Sarawak are also played a vital role towards Sarawak development.

\section{Methodology}

Figure 1 shows the framework of the research. The study employs a descriptive study design to describe the participation of Iban women in side-income earning such as respondents' profile, side-income activities, and obstacles in side-income earning. Thus, the information will be collected through the questionnaire. This research proposed two methods in data collection i.e., face-to-face interview and self-administered questionnaire. The faceto-face interview is purposedly for older respondents and for those who do not understand the questions while the self-administered questionnaire is for respondents who able to answer the questions. However, due to the pandemic Covid 19 and Movement Control Order (MCO) in Sarawak, the web-based survey by using Google Form is the best method to reach potential respondents in Sarawak. Judgement sampling is a non-probability sampling method will be used as researcher only focus on Iban women who involved in side-income earning, thus not all Iban women will has probability to include in this study. Descriptive data analysis will be used to describe and summarize the findings. Iban is a sub-ethnic group of Dayak where it is comprised almost $50 \%$ of the Sarawak population. According to Statistics Department Malaysia (2020), the population of the town of Bintulu is 266,200 . Based on census 2010, indigenous people accounted for the largest proportion of the town population $(61.2 \%)$, followed by Chinese $(25.0 \%, 28,512)$, non-Malaysians $(13.1 \%, 14,939)$, and Indians $(0.3 \%, 319)$. Among the indigenous groups, there are Iban $(32,992)$, Malay $(14,945)$, Melanau 
$(14,179)$, Bidayuh $(1,598)$, and other indigenous tribes $(6,068)$ (Statistic Department Malaysia, 2011).

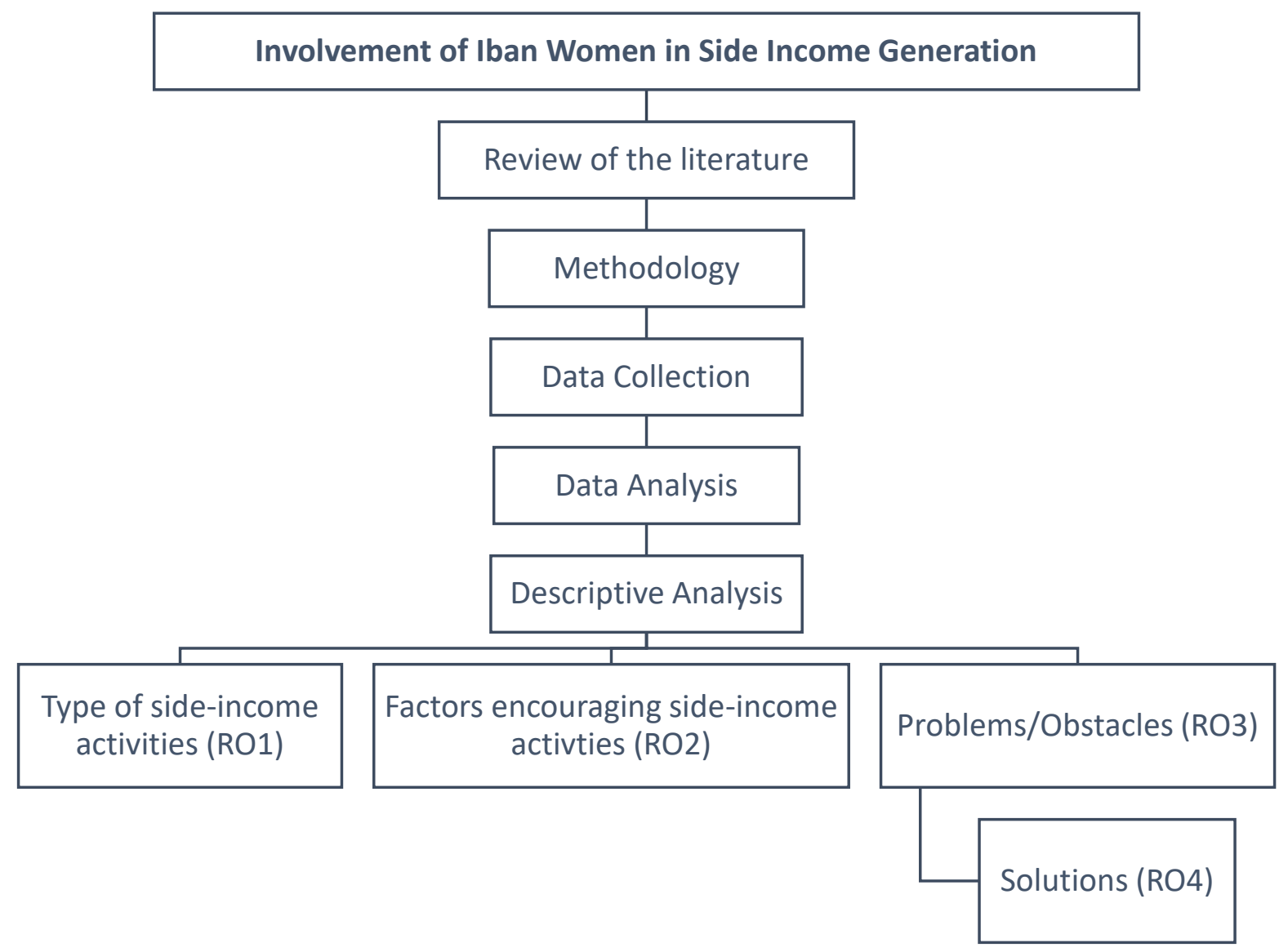

Figure 1: Framework of the Research

This research use both closed-ended and open-ended questions. The questionnaire is prepared in two languages, i.e., Malay and Iban. The questionnaire will be divided into three main sections as follows:

i. Section A - Respondent's background

a. Demographic characteristics - Location, age, status, education, occupation, income, number of family member

ii. Section B - Participation in side-income activities before pandemic and MCO

a. Type of activities

b. Reasons to participate in side-income earning

c. Marketing

d. Income

e. Obstacles

f. Suggestion to overcome the problems

iii. Section C - Side-income activities during pandemic and MCO.

a. Problem in side-income earning

b. Income

c. The ways they overcome the problems 


\section{Expected Outcomes}

Figure 2 shows the expected outcome from the research. The aim of this research is for Iban development and empowerment. There are two objectives we need to achieve i.e providing knowledge and skills to Iban women and providing financial support to encourage their participation in side-income earnings. Government or relevant agencies could plan and organizes courses or training to improve knowledge and skills. The are several activities could be conducted to support the side-income earnings among Iban women in Bintulu Sarawak. For instance, if they have products but do not know how to market, we can provide entrepreneurship and marketing training for them and guide them effective methods to market their products Meanwhile, if they have less or fewer skills and knowledge in handicraft making, food processing and even farming, we could provide training to them to enhance their skills. Like handicraft issues, most of young women staying in town areas do not know how to produce handicraft as they do not have opportunity to learn those skills from elder generation. We can arrange an intensive training to give opportunity to them to learn handicraft making from the expertise. Thus, such trainings could help them to do home business. Besides, to reduce financial burden, the providing financial support such as personal loans for those to start up business. Besides, and providing subsidies for rental services such as shop, kiosk, and transportation.

\section{Conclusion}

Relevant programs and trainings could help Iban women in side-income generation. However, the programs and trainings or courses should match with their needs. For instance, they may have good skills in handicraft making but they do not know how to market their products, they may need marketing management training. Iban women in town areas may not interested in handicraft making due to no or fewer skills and at the same time difficulty to have raw materials as traditional handicraft making heavily depend on the availability of natural resources such as bamboo, rattan, etc. For this case, they may need food processing courses as food and beverages have high demand in town areas. Thus, this study is important to know what they need to support their side-income activities. 


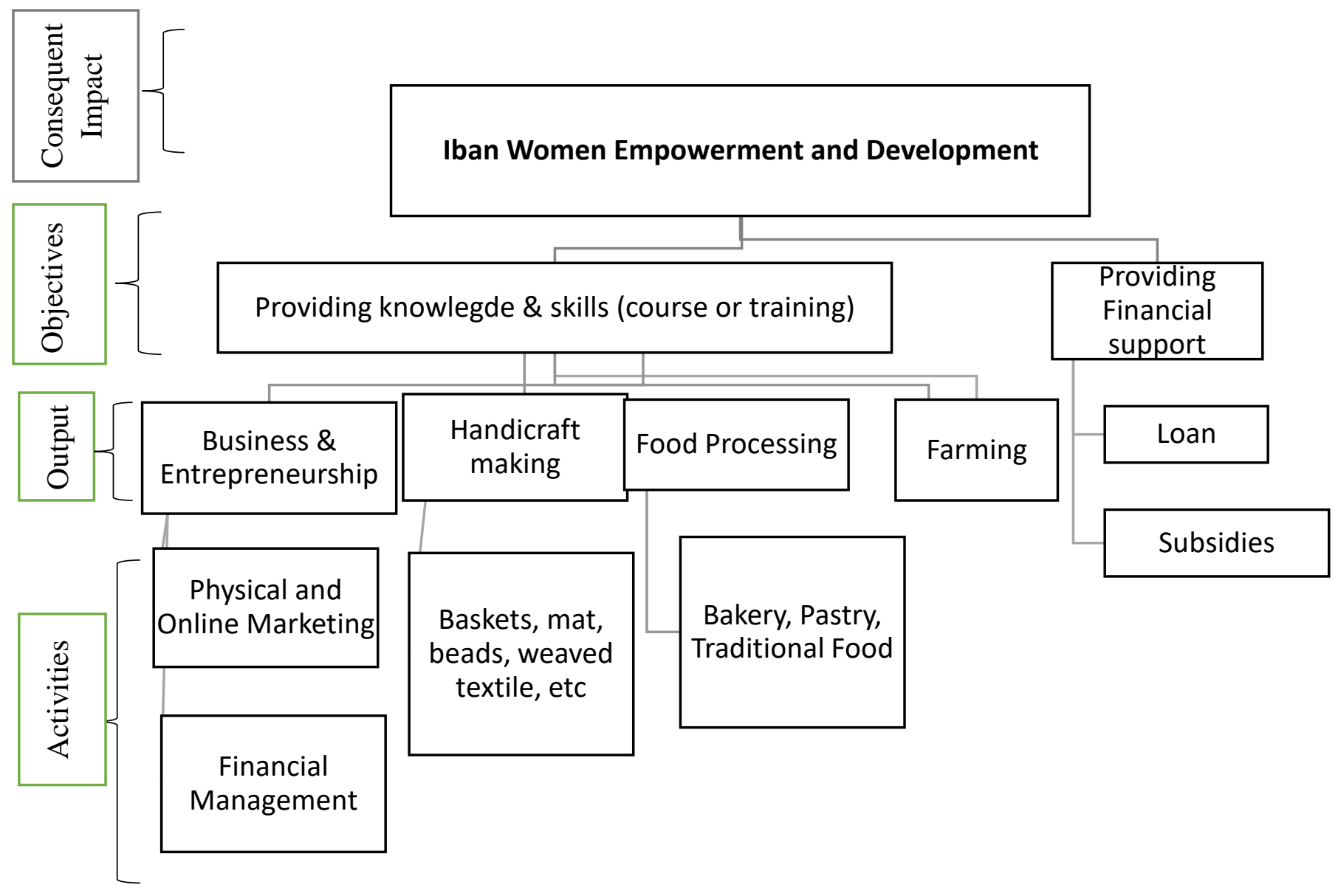

Figure 2: Expected Outcome

\section{Acknowledgement}

This research is funded by the Tan Sri Empiang Jabu Research Chair (TSEJRC) Grant.

\section{References}

Adedeji, O. A., Rapheal, A. O., Patience, F. T.-O., Olabosipo, I. F., Timothy, O. (2018). Survey datasets on women participation in green jobs in the construction industry. Data in Brief, 17, $856-862$.

Arpino, B., Pronzato, C. D., \& Tavares, L. P. (2014). The effect of grandparental support on mother's labour market participation: An instrumental variable approach. European Journal of Population, 30 (4), 369 - 390.

Borneo Post. (2019). Sarawak women on the rise. Borneo Post online. https://www.theborneopost.com/2019/12/30/sarawak-women-on-the-rise/

Department Of Statistics, Malaysia. (2020). Newsletter: Informal Sector in Malaysia, DOSM/BPTMS/3.2020/Series https://www.dosm.gov.my/v1/uploads/files/6_Newsletter/Newsletter\%202020/DOS M_BPTMS_3-2020_Series-51.pdf. 
Golshan, M., Faghihi, M., \& Marandiz, M. M. (2002). Indoor women jobs and pulmonary risks in rural areas of Isfahan, Iran. Respiratory Medicine, 96, $382-388$.

Ida, R., \& Nurliani (2016). A Review on Multi-Roles of Women and Their Influence on the Change of Functional Structure in the Farmer's Household. Agriculture and Agricultural Science Procedia, 9, $47-53$.

Kriesi, I., Buchmann, M., Sacchi. S. (2010). Variation in job opportunities for men and women in the Swiss labor market 1962 - 1989. Research in Social Stratification and Mobilty, 28, $309-323$.

Krumbiegel, K., Maertens, M., Wollni, M. (2020). Can employment empower women? Female workers in the pineapple sector in Ghana. Journal of Rural Studies, 80, 76 - 90.

Lipscomb, H. J., Dement, J. M., Epling, C. A., Gaynes, B. N., McDonald, M. A., Schoenfisch, A. L. (2007). Depressive symptoms among working women in rural North Carolina: A comparison of women in poultry processing and other low-wage jobs. International Journal of Law and Psychiatry, 30, $284-298$.

Padilla-Meléndeza, A., Ciruela-Lorenzo, A. M. (2018). Female indigenous entrepreneurs, culture, and social capital. The case of the Quechua community of Tiquipaya (Bolivia). Women's Studies International Forum, 69, $159-170$.

Pattnaik, I., \& Lahiri-Dutt, K. (2020). What determines women's agricultural participation? A comparative study of landholding households in rural India. Journal of Rural Studies, 76, $25-39$.

Statista. (2021). Share of females employed in the informal sector from total female employment in Malaysia from 2011 to 2019. https://www.statista.com/statistics/974037/informal-sector-as-share-of-total-femaleemployment-malaysia/.

Statistics Department, Malaysia. (2020). Population by administrative district and ethnic group, Sarawak. https://sarawak.gov.my/web/home/article_view/240/175/.

Saadina, I., Ramli, K., Johari, H., Harin., N. A. (2016). Women and Barriers for Upward Career Advancement - A Survey at Perak State Secretariat, Ipoh, Perak. Procedia Economics and Finance, 35, $574-581$.

Sassler, S., Glass, J., Levitte, Y., Michelmore, K. M. (2017). The missing women in STEM? Assessing gender differentials in the factors associated with transition to first jobs. Social Science Research, 63, $192-208$.

United Nation Women Watch. (2009). Women, Gender Equality and Climate Change [Fact sheet], United Nations. https://www.un.org/womenwatch/feature/climate_change/ 